\title{
契煙における $\dot{\mathrm{V}} 25 / \mathrm{H}$ と 1 秒率の検討
}

\section{○前田 保久 若林 良明 田中健夫 大林 秀幸}

フローボリューム曲線は, 従来のスパイロメーター等 では検出できなかった細気管支領域の閉塞性病变を初期 のうちに把握し，とくに唖煙者にみられる呼吸器障害の 早期発見に有用な検査方法といわれている。

第12回の本学会に拈いて, $\dot{\mathrm{V}} 25 /$ 身長補正, 以下/H, の正常値の設定に加え, 非䒜煙者と各喫煙群との関 係 を，第 2 報において，例数をふやして $\dot{V} 25 / \mathrm{H}$ と 1 秒率 の成績の有意差検定を行なって報告をした。

今回は, 昭和 59 年 4 月 1 日より 60 年 3 月 31 日までの総 合健診受診者で, \%肺活量が 80 以上で, 気管支炎, 肺気 腫などの肺疾患を除いた男子 15,605 名, 女子 4,127 名に ついて非契煙者と契煙者に分け，さらに契煙者について は, Smoking index（一日の契煙本数 $\times$ 契煙年数）以下 S.I, により 0, 1〜 199, 200〜399, 400〜799, 800 以上 の群に分け, $\dot{\mathrm{V}} 25 / \mathrm{H}$ と 1 秒率の関係等を検討して若干 の知見を得たので報告する。

測定にはモーガン製スパイロメーター M8 型, サニ タ製スパイロコンピュータートラコムジュニア V-02を 用いた。

年齢別の S.I と $\dot{V} 25 / \mathrm{H}$ の異常率の関係は, 40歳代 で S.I=0 の $4.5 \%$ に対して，1〜199は4.6\%ほぼ同じ, 200〜399は5. 5\%やや上昇，400～799は9.5\%で約 2 倍， 800 以上は $13.1 \%$ で約 3 倍であった。 50 歳代も同じよう な傾向を示した。

S.I 別の年路令と $\dot{\mathrm{V}} 25 / \mathrm{H}$ の異常率の関係は, 各喫煙群 とも年齢の増加にともない異常率も上昇し, S.I が400 〜799以上の群から，30歳代と40歳代では有意な差が み られた。女性の哭煙者は非契煙者に対して，40歳代から
有意な差が認められた。1 秒率の異常率は各掣煙群とも 年齢の増加により上昇を示して $\dot{V} 25 / \mathrm{H}$ に対し約 10 分の

1 であった。

V $25 / \mathrm{H}$ の限界值未満の群の中で Lage Air Way への 障害の及んでいる者の割合をみるために，1 秒率の $70 \%$ 以上と $69 \%$ 以下に分けて検討した。1 秒率が $69 \%$ 以下で V $25 / \mathrm{H}$ が限界值未満の者の平均年龄は55歳であり, 異 常率は $\mathrm{S} ・ \mathrm{I}=400$ 以上，50歳代から上昇を示した。 1 秒率が $70 \%$ 以上で $\dot{V} 25 / \mathrm{H}$ が限界值未満の者では平均年 齢は48歳であり，差は 7 歳であった。

契煙による $\dot{V} 25 / \mathrm{H}$ の異常率の上昇は，たとえば，30 歳の人が 5 年間 1 日 20 本タバュを吸うと S.I は 100 に なり異常率は3.6\%である。このまま吸い続けると40歳 では S.I は300になり異常率は $5.5 \%$ になる。年齢と喫 煙量の増加に伴い10年間で約 2 倍の異常率の上昇がみら れた。

各 S.I による $\dot{V} 25 / \mathrm{H}$ の平均值の変化をみると, S.I が多くなれば平均值も低下し，分布もマイナスの 方にシフトしていた。S.I=0 を基準にすると， 1 199 で 1\%上昇，200〜399で 3\%低下，400〜799で 9\%低 下，800以上で15\%の低下を示した。また，女性の契 煙 者は非契煙者に対して $4 \%$ の低下であった。

今回は, 契煙量と $\dot{\mathrm{V}} 25 / \mathrm{H}$ の関係を異常率から検討し た。細気管支領域の異常は，40歳代で, S.I が 400 以上 から顕著になり，年齢と契煙量と共に増加した。

$\dot{\mathrm{V}} 25 / \mathrm{H}$ の検討は, 1 秒率に比べ細気管支領域の 障 害 の状態を早期にチェックするのに有効である。

\section{Relationship between $\dot{\mathrm{V}} 25 / \mathrm{H}$ and FEV $1.0 \%$ influence of smoking -}

愛知県総合保健センター 